\title{
THE IDENTITY AND TYPE SPECIMENS OF COLLOHMANNIA ASIATICA (ACARI, ORIBATIDA, COLLOHMANNIIDAE)
}

\author{
Ekaterina A. Sidorchuk ${ }^{1 *}$ and Roy A. Norton ${ }^{2}$
}

\author{
${ }^{1}$ Paleontological Institute, Russian Academy of Sciences, Moscow, Russia \\ ${ }^{2}$ State University of New York, College of Environmental Science and Forestry, Syracuse, \\ New York, USA \\ *corresponding author; e-mail: e.a.sidorchuk@gmail.com
}

\begin{abstract}
Three extant species of the oribatid mite genus Collohmannia (Collohmanniidae) have been named, of which two, C. gigantea Sellnick, 1922 and C. johnstoni Norton et Sidorchuk, 2014, are well known. The third-C. asiatica Krivolutsky et Christov, 1970-is known only from a brief, insufficient original description. Our purpose was to study and illustrate the slidemounted and damaged type series of $C$. asiatica (male holotype, male and female paratypes) from Tajikistan and to redescribe the species using as much morphological information as could be extracted. Based on 18 characters that vary among the three species, $C$. asiatica is more closely related to the European $C$. gigantea than to the North American C. johnstoni. Similarities of the two palaearctic species that we consider synapomorphous include two that are common to both sexes-tarsus I thickened and bearing six solenidia—and two that are male-specific: relatively short legs IV, and elongated distal setae $(\tau d)$ on the spermatopositor.
\end{abstract}

KEY WORDS: Oribatid mite, soil, Collohmannia, Mixonomata, redescription, taxonomy, Tajikistan.

DOI: 10.21684/0132-8077.2016.24.1.5.16

\section{INTRODUCTION}

The holarctic family Collohmanniidae (infraorder Mixonomata) are large (1-2 mm), litterdwelling oribatid mites that are unusual in exhibiting associative mating behavior and sexual dimorphism related to the transfer of nuptial food. The significant attention paid in the literature to this reproductive biology, in addition to general anatomy, chemical ecology, development, and phylogenetic relationships (reviewed by Norton and Sidorchuk 2014, 2015) contrasts strongly with the low known diversity of five named species. Three of these are extant and two are represented by fossils.

From a morphological standpoint, two of the extant species are relatively well known. The European type species-Collohmannia gigantea Sellnick, 1922 - was collectively redescribed in all instars by Sellnick (1932, as the synonym C. nova Sellnick), Grandjean (1966) and Pfingstl et al. (2005); Štorkán (1925) illustrated an adult Collohmannia, supposedly $C$. gigantea, but we doubt the identification. All instars of the North-American C. johnstoni Norton et Sidorchuk, 2014 also have been described. The third species-C. asiatica Krivolutsky et Christov, 1970 (in Christov 1970) from Tajikistan - has been known mostly from the short original description of the adult. The two named fossil species are both European, from Baltic amber. Collohmannia schusteri Norton, 2006 is based on only the holotype male. Embolacarus pergratus (Sellnick, 1919) is the type of the mono- typic genus Embolacarus. The latter was transferred to Collohmanniidae (Norton 2006) and thought to be a synonym of Collohmannia, but all original material has been lost (see also Norton and Sidorchuk 2014, 2015).

The original description of C. asiatica was very brief and accompanied by a single rather simplistic and misleading illustration of the dorsal view. Christov (1970) indicated that a more complete description of the species would be published in a separate journal, but this never happened. Our purpose is to redescribe $C$. asiatica to the extent allowed by existing type material, and to compare the salient traits of the three named extant species of Collohmannia.

\section{MATERIAL AND METHODS}

Specimens. According to the original description (Christov 1970), the type material comprised three specimens, all from moss in Varzob Gorge, in the southern part of the Hisor (Gissar) mountain range in west-central Tajikistan, about $30 \mathrm{~km}$ north of Dushanbe. We have studied the holotype male (Fig. 1), deposited in the Laboratory of Soil Ecological Functions, A. N. Severtsov Institute for Problems of Ecology and Evolution (Moscow, Russia) and two paratypes (male, female; Fig. 2) deposited in the collection of the Tyumen State University Museum of Zoology (Tyumen, Russia). Each was originally mounted on a flat glass microscope slide in what appeared to be glycerin-gelatin medium, the deterio- 


\section{E. A. Sidorchuk and R. A. Norton}

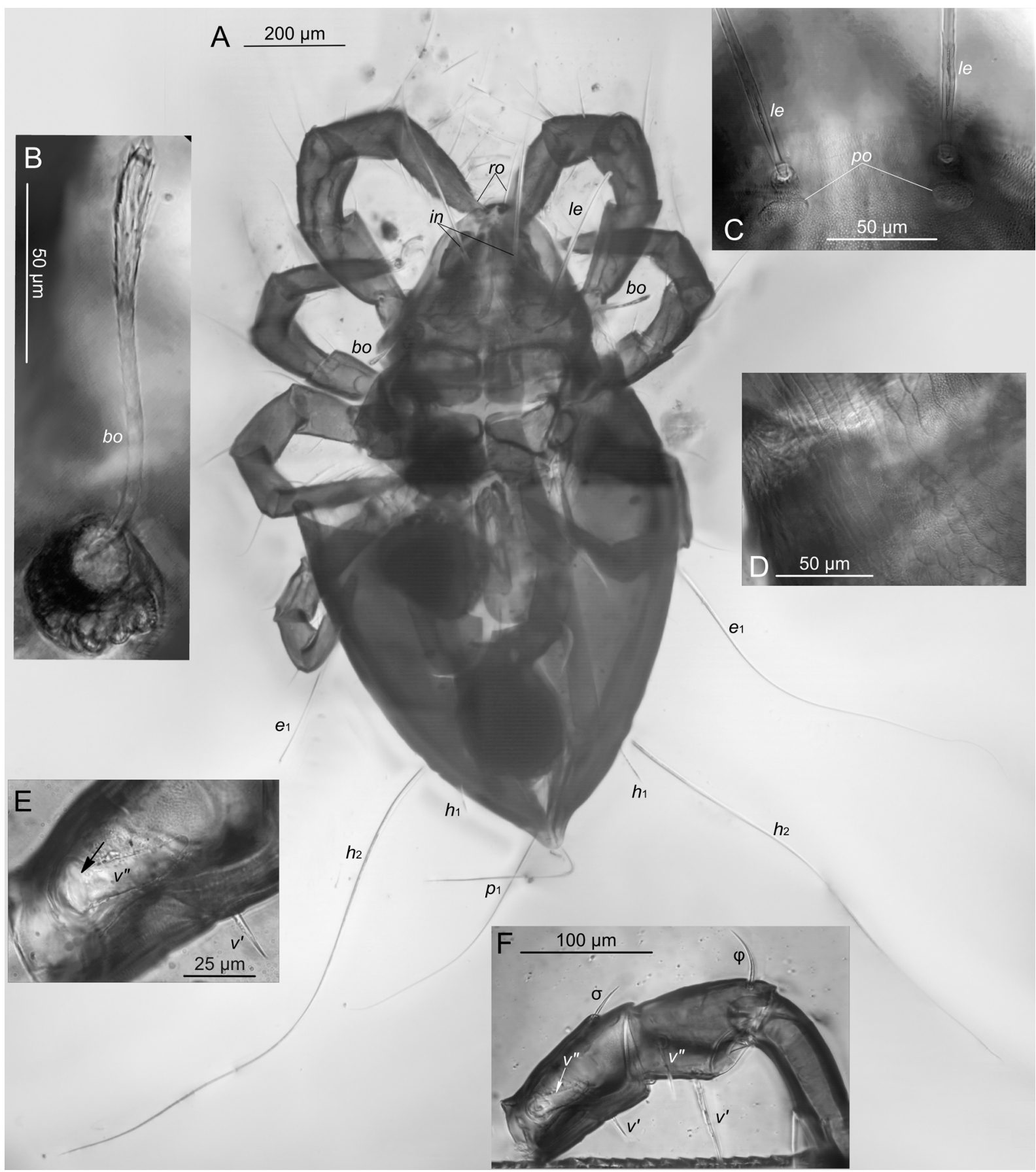

Fig. 1. Collohmannia asiatica. holotype male, layered light micrographs. A, habitus, ventral view; B, bothridial seta (bo) and bothridium; C, setae le and porose areas (po); D, notogastral cuticle in area of $e$-setae; E, genu IV, showing hypertrophied seta $v^{\prime \prime}$ and ridge on outer face of its broadened part (arrow); F, genu, tibia and basal part of tarsus IV (E, $\mathrm{F}$ adaxial view).

ration of which left each mite damaged and the preparations unusable. Observations recorded here were made after remounting the broken and delicate specimens in Euparal medium between two coverglasses held in Cobb's aluminum slide holders.

Observation and documentation. Observations were made with Jenaval and Nikon E800 microscopes, under bright-field or Nomarski (DIC) illumination with dry or immersion lens (oil or water). Light micrographs were obtained with a Scope Tec DCM 500 digital camera on the Jenaval (holotype) and with an AmScope Mu900 on the Nikon E800 (paratypes). When appropriate, image stacks were combined using the Helicon Focus Pro (v. 5.0) suite; these are indicated below as 'layered.' Most of the images were corrected for color, contrast and clarity with Adobe Lightroom 5. Drawings were made with a Wacom Intuos $4 \mathrm{M}$ pen tablet 


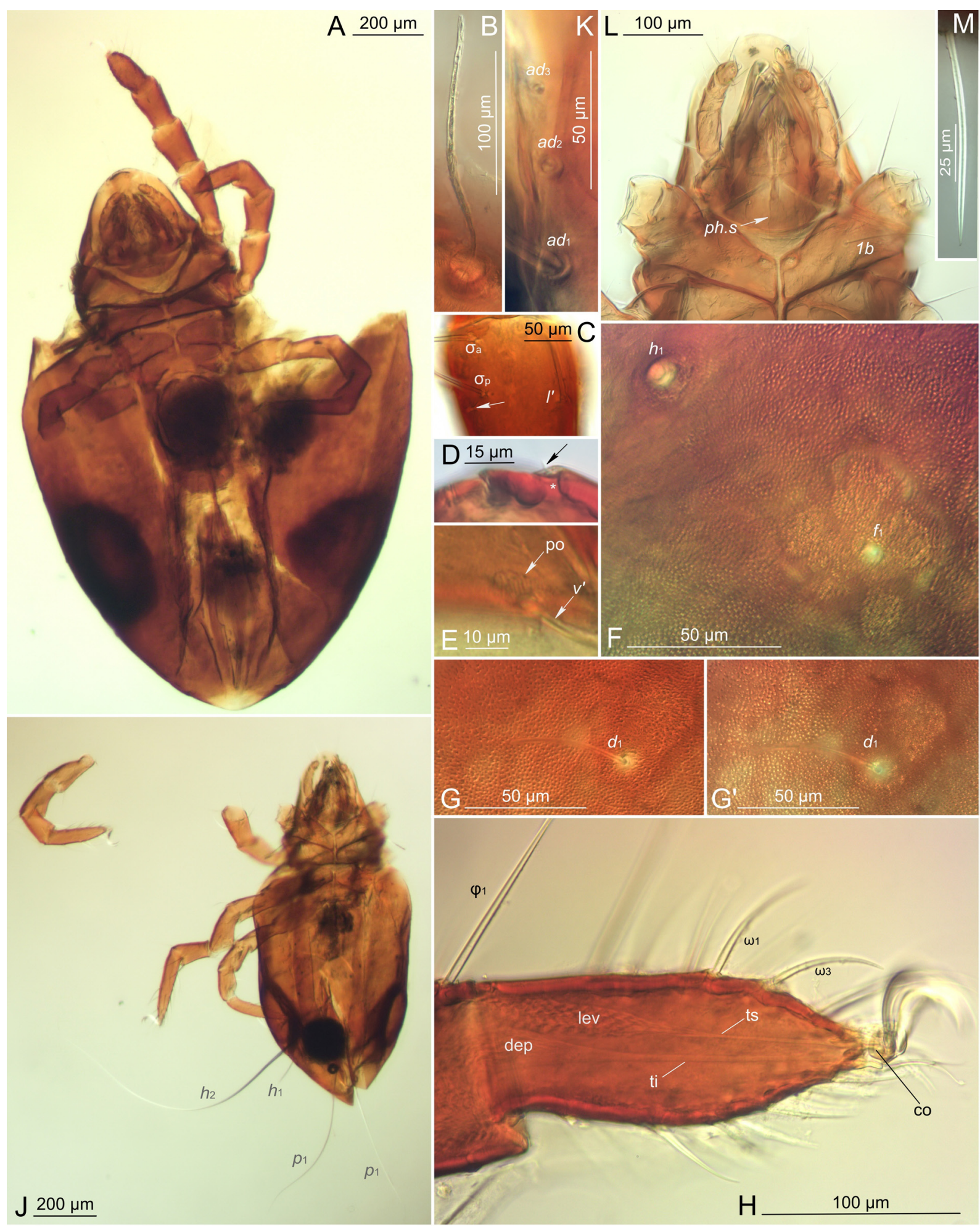

Fig. 2. Collohmannia asiatica paratypes, layered (except E) light micrographs. A-H, female: A, overview (ventral view); B, bothridial seta; C, distal part of genu I, arrow points to genual pore; D, fragment of tibia II, showing socket (*) of displaced solenidion, arrow points to minute seta $d$; E, fragment of femur IV, showing porose area ( $p o$ ) at base of seta $v^{\prime} ; \mathrm{F}-\mathrm{G}$, notogastral porose areas, anterior to right: G, porose area associated with seta $d_{1}$ (bright field); G', same, in polarized light; F, porose area associated with vestige of seta $f_{1}$ and alveolus of displaced seta $h_{1} ; \mathrm{H}$, tarsus I, showing distal part of levator (lev), whole depressor ( $d e p)$ muscles of ambulacrum, their respective superior $(t s)$ and inferior $(t i)$ tendons, and articulating condyle of ambulacrum $(c o) ; \mathrm{J}-\mathrm{M}$, male: J, overview; K, right adanal plate, showing relative sizes of adanal setae alveoli; L, coxisternum (anterior part) and gnathosoma with pharyngeal sclerite ( $p h . s$ ) visible by transparency; M, notogastral seta $h_{1}$. 


\section{E. A. Sidorchuk and R. A. Norton}

using a live capture from the camera transferred through a VLC media player (v. 0.9.9) as a background in the InkScape graphic suite (Sidorchuk and Vorontsov 2014). In drawings, setae that terminate unnaturally are either broken on the specimen (marked with X), or truncated for lack of space (marked with small transverse line).

Terminology and measurements. Morphological terminology is mostly that of F. Grandjean (see Travé and Vachon 1975 for references, Norton and Behan-Pelletier 2009 for overview). When possible, measurements that differ noticeably between female and male are given separately, identified respectively by $\mathrm{F}$ and $\mathrm{M}$; metric data for the two males are ranges or single numbers depending on availability. Setal and solenidial formulas are given as number per leg (I-IV) for appendage segments and as number per podosomal segment (I-IV) for epimeres. Body dimensions should be considered approximations because of the broken nature and flattening of the specimens, particularly the notogaster; no attempt was made to measure notogastral maximum width. The inability to study specimens at various angles meant that measurements of setae lying obliquely in the preparations could only be estimated $(\sim)$. Paired structures are described in the singular unless noted. Unless otherwise indicated, parentheses around leg setal notations denote the two members of a pseudosymmetrical pair on a given leg segment, rather than a true bilateral pair.

\section{Redescription of Collohmannia asiatica Krivolutsky et Christov, 1970}

Figs. 1-5

Diagnosis. Collohmannia species (see Norton and Sidorchuk 2014) with total length 1160-1620 $\mu \mathrm{m}$. Bothridial seta thin, isodiametric (F) or slightly clavate (M), with small barbs. Notogaster with three flagellate setae (at least in male): $e_{1}, h_{2}$ longest, $p_{1}$ half their length; seta $h_{1}$ short, stiff, acicular. Adanal setae $a d_{1}, a d_{2}$ with twice thickness of anals and $a d_{3}$. Tarsus I with 6 solenidia and about 40 setae; without ribbon-like neotrichous setae in male. Male leg IV with genu and tibia of about equal length; tibia unmodified, seta $v^{\prime}$ inserted proximal to mid-length of segment; genu seta $v^{\prime \prime}$ thumb-like, inserted far proximally, tip not approaching articulation with genu.

General features. The female (total length ca. $1620 \mu \mathrm{m})$ is of typical size for the genus, but the male $(1160-1247 \mu \mathrm{m})$ is smallest among extant species. Cross-sectional shape of the hysterosoma can be diagnostic in the genus, but was not measurable in the type series; the ovate, posteriorly narrowed shape shown by Christov (1970; his Fig. 3), and indicated even in the damaged specimens (Figs. $1 \mathrm{~A}, 2 \mathrm{~A})$, suggests that overall shape is more like that of $C$. gigantea than the broader $C$. johnstoni.

Prodorsum. The overall shape of the prodorsum is typical of Collohmannia, subtriangular with a broadly rounded rostrum. The only porose areas evident are the small, transversely oriented elliptical pair immediately posterior to insertions of lamellar setae (po, Figs. 1C, 3A). The sagittal apodeme $(75 \mu \mathrm{m} \mathrm{M}, 110 \mu \mathrm{m} \mathrm{F})$ is well marked in both sexes ( $s a$, Fig. 4A). Most setae are simple, flexible, weakly barbed, with typical positions and proportions, increasing in the order $x p(\sim 15 \mu \mathrm{m}), x a$ (34-50 $\mu \mathrm{m})$, ro $(175-200 \mu \mathrm{m})$, le $(410-420 \mu \mathrm{m})$, in ( $\sim 520, \mathrm{~F}$ only). Mutual distance between members of setal pairs ro, le, in are 35-40, 65-100 and 175-250 $\mu \mathrm{m}$, respectively. The bothridium (Figs. $1 \mathrm{~B}, 3 \mathrm{C}$ ) has a small opening and several dozen descending locules (outpockets). The bothridial seta (bo) appears to be dimorphic: in the female $(\sim 190 \mu \mathrm{m}$, present only on left) it is slightly curved, thin, isodiametric, with minute barbs along its length but denser distally (Fig. 2B); in the male $(\sim 130-150 \mu \mathrm{m})$ it is weakly clavate, with barbs conspicuous on the narrow head, sparse and minute on the stalk (Figs. 1B, 3C).

Notogaster. The notogaster has an imbricate cuticular pattern similar to that of other species (Figs. 1D, 2A), with cells near the anterior and anteroventral margin being elongated parallel to the edge, giving a vaguely striated appearance. Notogastral setae are preserved best in the holotype, and worst in the female paratype, which retains only the smaller setae on the body. All setae are smooth, or nearly so, and size heterogeneity is strongly developed, as is typical of the genus; however, the specific size distribution is unique. In the males (Fig. 3A) there are three conspicuous, flagellate setae: $e_{1}(843 \mu \mathrm{m})$ and $h_{2}(1090-1100$ $\mu \mathrm{m})$ are approximately as long as the notogaster, $p_{1}(570-600 \mu \mathrm{m})$ about half as long. Seta $h_{1}$ is short $(90-100 \mu \mathrm{m})$, stiff, acicular, erect and relatively thick (Fig. 2M). While none of the above setae are on the paratype female's body, several long setae are detached in the nearby medium. Two are barbed (Fig. 4A), and almost certainly represent prodorsal setae in and $l e$ (see above). Three others are flagellate but smooth (Fig. 4B), and must represent at least two of the three setal pairs that are flagellate on the male notogaster; two are $700 \mu \mathrm{m}$, the third 


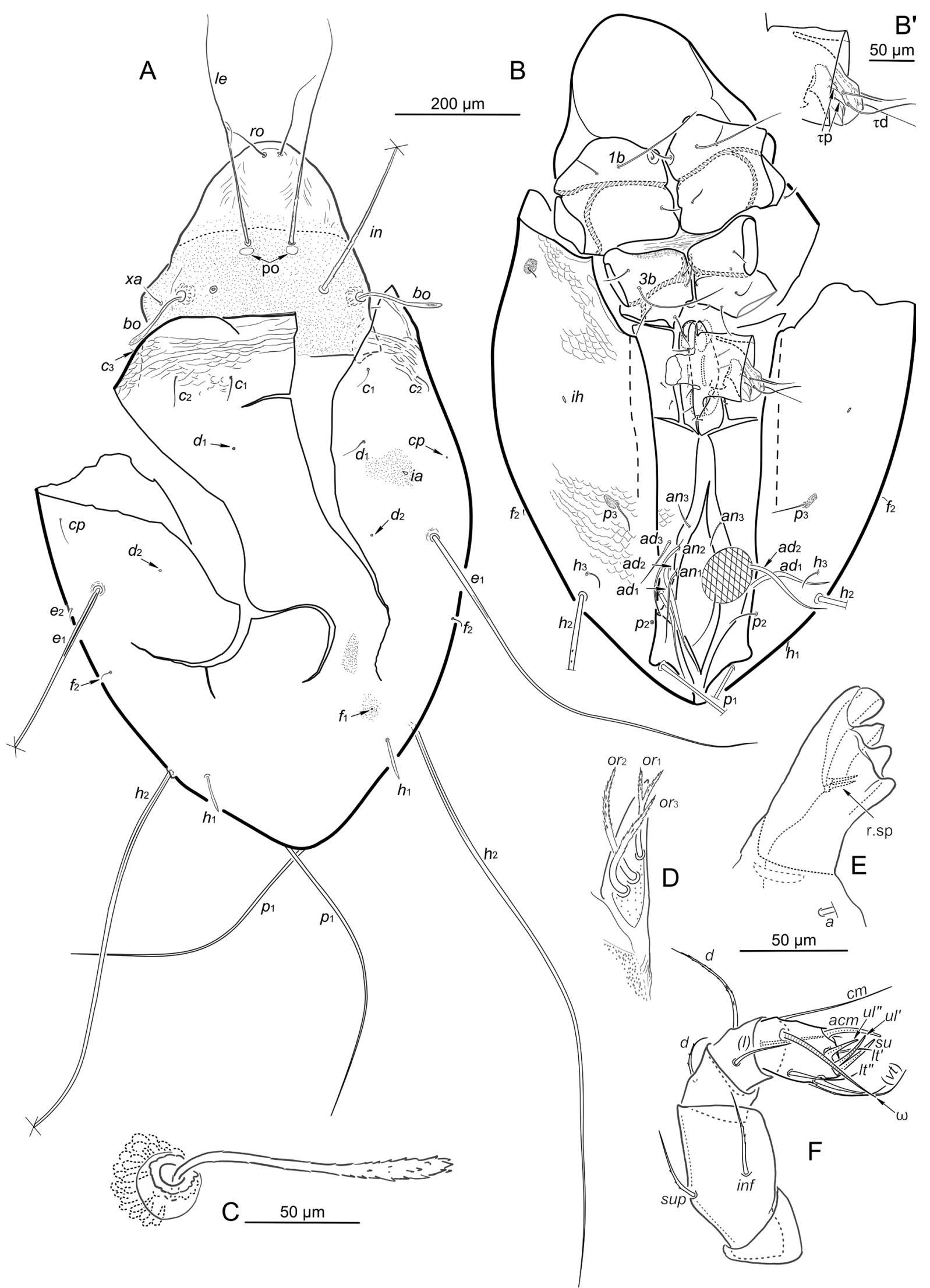

Fig. 3. Collohmannia asiatica, holotype male. A, dorsal view, legs not shown, several setae broken or displaced (in, $\left.c p, d_{1}, d_{2}\right)$, vestigial seta $f_{1}$ not discerned on left; $\mathrm{B}$, ventral view, legs and gnathosoma not shown, dark particle obscures part of anal region; B', tip of spermatopositor; C, bothridial seta; D, right lateral lip, ventral view; E, left rutellum, ventral view, flipped; F, left palp, abaxial view, flipped (tarsus and genual seta $d$ foreshortened). Abbreviation: $p o$, porose area. 


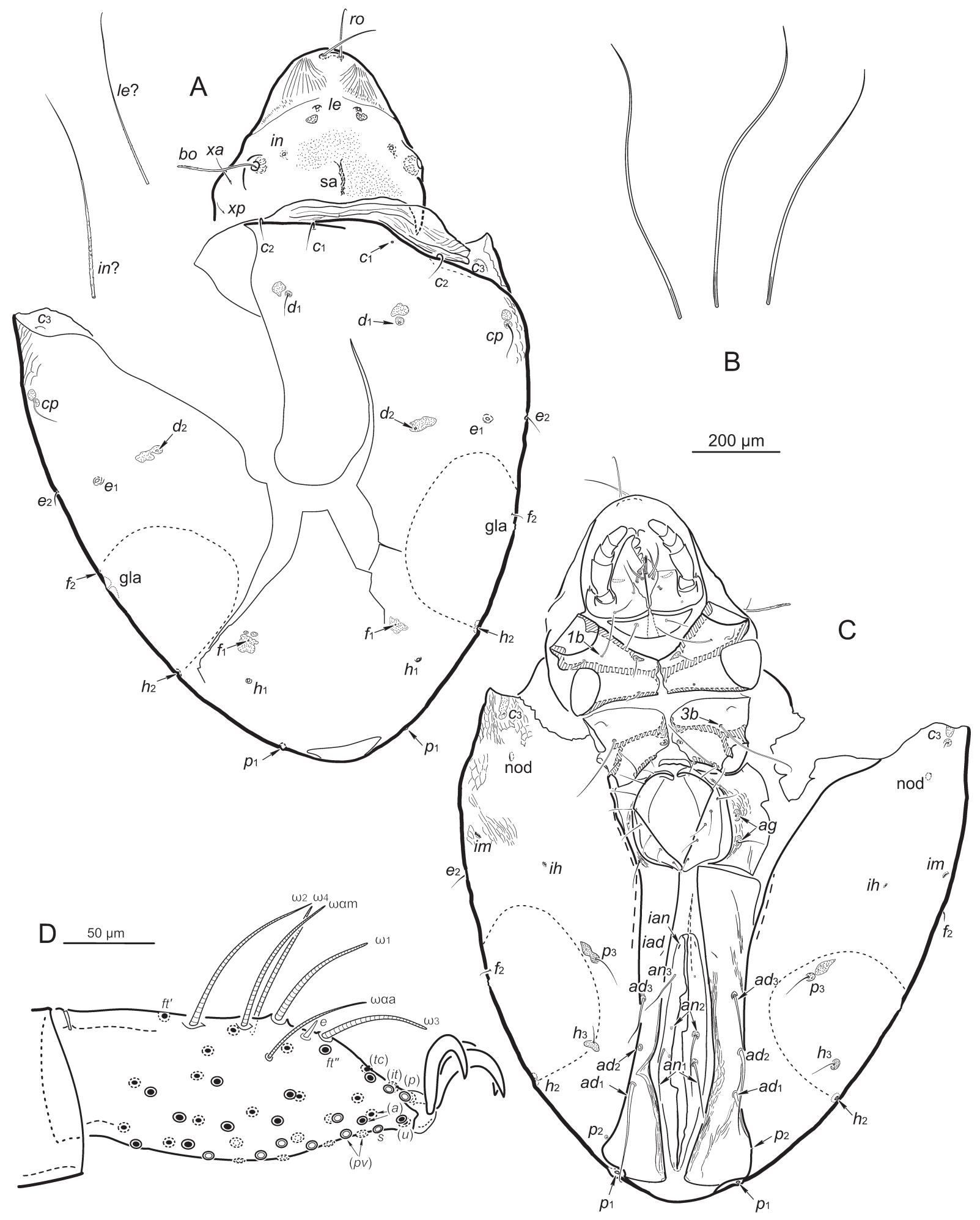

Fig. 4. Collohmannia asiatica female paratype. A, dorsal view, legs not shown, most setae displaced or broken, probable setae le and in shown separately at upper left; $\mathrm{B}$, unidentified displaced setae, probably flagellate notogastral setae; $\mathrm{C}$, ventral view, legs not shown; D, right tarsus I, schematic abaxial view (slightly foreshortened): circles and ovals with full outlines indicate alveoli of posterior (") setae, those with dotted lines indicate anterior (') setae; solid internal circles indicate normal setae, open internal circles indicate eupathidia. Abbreviation: $s a$, sagittal apodeme. 


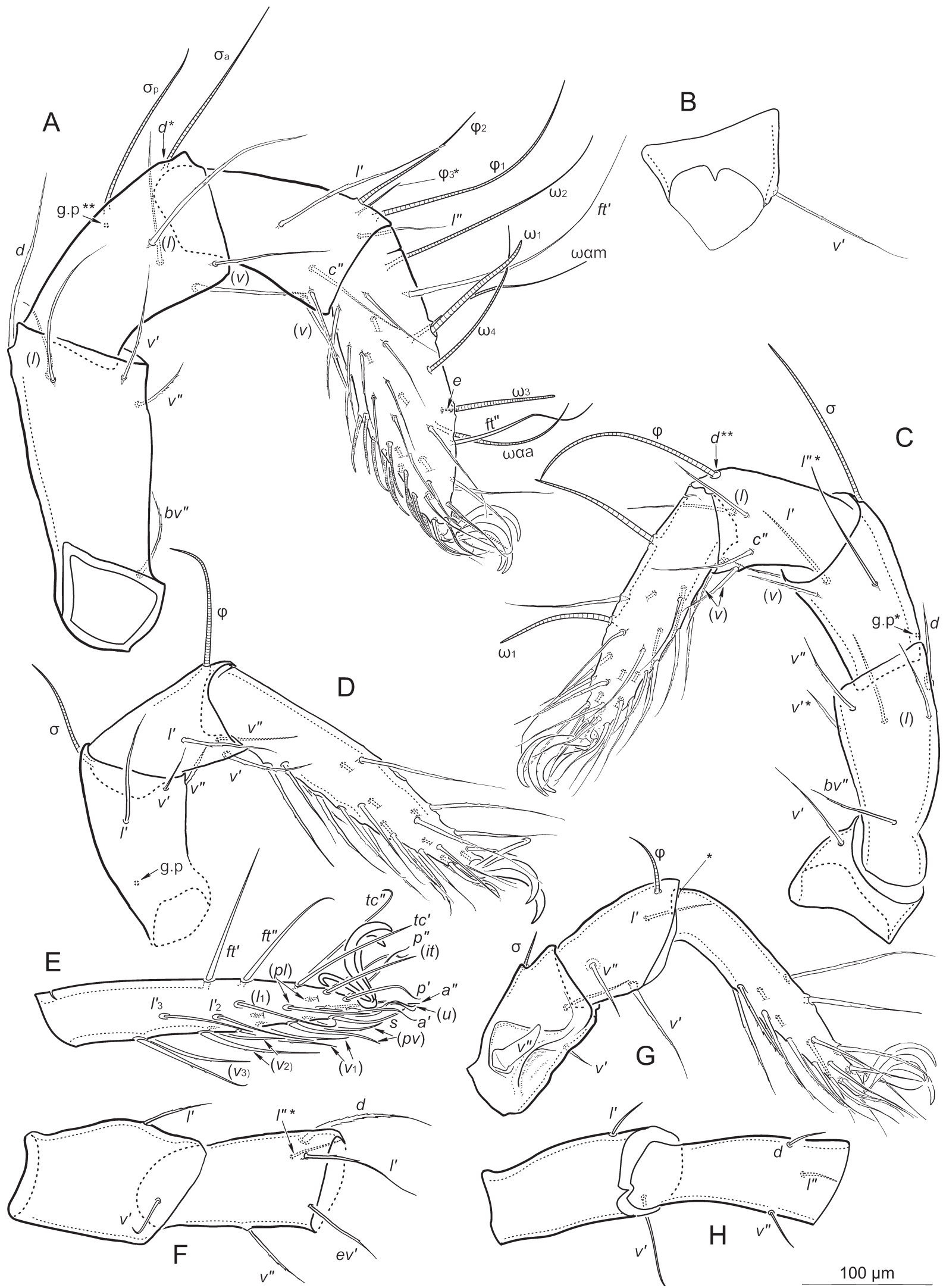

Fig. 5. Collohmannia asiatica males, legs. A-D, F, H, holotype; E, H, paratype. A, leg I, femur-tarsus; B, leg I, trochanter; C, leg II; D, leg III, genu-tarsus; E, leg III, tarsus; F, leg III, trochanter and femur; G, leg IV, genu-tarsus; H, leg IV, trochanter and femur, flipped. A, B, G, adaxial; C-E, H, abaxial; F, ventral view. Abbreviation: g.p, genual pore. * - observed on paratype male and female but not confirmed in holotype; ${ }^{* *}$ - observed on paratype female but not confirmed in holotype and paratype males. 


\section{E. A. Sidorchuk and R. A. Norton}

$625 \mu \mathrm{m}$ long. If the latter represents the shortest of the male setae $\left(p_{1}, 570-600 \mu \mathrm{m}\right)$, then the former two must represent $e_{1}, h_{2}$ or both (these are between $843-1100 \mu \mathrm{m}$ in males). So, we suspect that $e_{1}$ and $h_{2}$ will be both proportionally and absolutely somewhat shorter in intact females than in males.

All other notogastral setae are short, fine and flexible: $c_{1}(50 \mu \mathrm{m}), c_{2}(50-60 \mu \mathrm{m}), c_{3}(20-25 \mu \mathrm{m})$, $c p(60-90 \mu \mathrm{m}), d_{1}(50-55 \mu \mathrm{m}), d_{2}$ (all broken, but with alveolus like that of $\left.d_{1}\right), e_{2}(24-50 \mu \mathrm{m}), f_{2}$ (24-50 $\mu \mathrm{m}), h_{3}(60-75 \mu \mathrm{m}), p_{2}(50-65 \mu \mathrm{m}), p_{3}$ $\left(55-85 \mu \mathrm{m}\right.$ ). The alveolar vestige of seta $f_{1}$ (Figs. $2 \mathrm{~F}, 4 \mathrm{~A})$ is well marked and covered with epicuticle; although seta $d_{2}$ is not intact on any specimen, it is certainly not vestigial, being represented by a minute broken stub.

On the female, insertions of most small, fine setae are associated with small porose areas that usually are irregularly shaped, asymmetrical, and less well-defined against the general background porosity than those of the prodorsum (Figs. 1C, 2G, $\left.\mathrm{G}^{\prime}, 4 \mathrm{~A}\right)$; none were seen at the base of the $\operatorname{stiff}\left(h_{1}\right)$ or flagellate $\left(e_{1}, h_{2}, p_{1}\right)$ setae. Most porose areas are less distinct in the males and their presence was often equivocal. In both sexes, the setal insertion usually is either central or eccentric, but well within the porose area (or within part of it, if the area is subdivided). Overall, the longest dimension of a porose area ranges from 5 to $70 \mu \mathrm{m}$ (mostly $10-25 \mu \mathrm{m})$. The opisthonotal gland opening ( $\mathrm{gla}$ ) is normal and distinct in the paratypes, though unconfirmed in the holotype; the glands themselves are large and conspicuous in both sexes. Though almost certainly present, lyrifissures were mostly unobservable in any preparation, with two exceptions: ih is small and pore-like, isolated on the ventral curvature, anterior to seta $p_{3}$; im (confirmed only in female) is small, but slit-like, anterodorsal to ih (Figs. 3B, 4C). A small nodule (nod), posterior to seta $c_{3}$ and serving for tendon attachment, is apparent on both paratypes but unconfirmed on the holotype. Similar nodules, also with attached tendons, are present between setae $d_{1}, c_{3}$ and $c p$ on the female.

Venter (Figs. 3B, 4C). The coxisternum is typical of the genus: broadest anteriorly and clearly divided into four units by sagittal and sejugal scissures; an internal ridge forms an apparent lateral fork in epimeral border 3 , just posterolateral to seta $3 b$. The epimeral setation is normal, 3-1-3-4; all are smooth and finely attenuate, but setae $1 b(170-220 \mu \mathrm{m})$ and $3 b(220-290 \mu \mathrm{m})$ are notably longer than others $(50-60 \mu \mathrm{m})$. Genital valves are distorted in all specimens, but seem normal for the genus; the female has a symmetrical setation of eight pairs of smooth, fine setae (35-85 $\mu \mathrm{m}$, smallest posteriorly), but setation in males was undetermined. The anal valves are also distorted in all specimens, but have the usual small lyrifissure ian near the anterior end, and three aligned pairs of smooth, attenuate setae; $a n_{2}$ is slightly longer $(150-170 \mu \mathrm{m})$ than $\mathrm{an}_{1}(\sim 130 \mu \mathrm{m})$ and $\mathrm{an}_{3}(60-120$ $\mu \mathrm{m})$. The aggenital plates are large and narrowly separated from the respective adanal plate by soft cuticle; the two pairs of simple aggenital setae $(\sim 25$ $\mu \mathrm{m} \mathrm{M}, \sim 70 \mu \mathrm{m} \mathrm{F})$ are longitudinally aligned $\left(a g_{1}\right.$, $\left.a g_{2}\right)$. A small porose area surrounds the alveolus of aggenital setae in both sexes. The adanal plates are the longest of the ventral sclerites, subrectangular when seen flat; lyrifissure iad is positioned in the anterior quarter, lateral to ian. The three adanal setae are evenly spaced in the central third: $a d_{1}$ $(175-180 \mu \mathrm{m} \mathrm{M}, 245 \mu \mathrm{m} \mathrm{F})$ and $a d_{2}(200-230 \mu \mathrm{m})$ are about twice as thick (Fig. 2K) as $a d_{3}(100-115$ $\mu \mathrm{m} \mathrm{M}, 125 \mu \mathrm{m} \mathrm{F})$. At least in the female, a small porose area surrounds the alveolus of $a d_{1}, a d_{2}$ and $a n_{3}$ (could not be confirmed in either male). Detailed features of the female ovipositor could not be discerned, but the male spermatopositor is partly extruded in the holotype; it is large, like that of other Collohmannia species (Fig. 3B') but its length could not be measured. Terminal eupathidia $\tau d$ are long and flexible $(\sim 100 \mu \mathrm{m})$, while $\tau p$ are much shorter $(\sim 20 \mu \mathrm{m})$; other setae and structures were not discerned.

Gnathosoma. Visible aspects of the gnathosoma are typical of the genus. Ventral characters of the subcapitulum (Figs. 2L, 4C) do not differ notably from those of $C$. johnstoni: the mentum is small, triangular, with a single pair of setae; each of the paired genae has two ventral setae, and a short, baculiform postpalpal seta on the dorsolateral corner; each lateral lip (Fig. 3D) has one bifurcated $\left(o r_{1}\right)$ and two simple setae $\left(o r_{2}, o r_{3}\right)$, all barbed in their distal half; and each rutellum (Fig. $3 \mathrm{E})$ has four strong distal teeth, a smaller dorsal tooth, and two or three isotropic spines ( $r . s p)$ on the dorsal face. The latter may be almost parallel thin spines, or two may be thinner, setiform and diverging from the other. The pharyngeal sclerite (ph.s, Fig. 2L) is distinct in the male paratype and lacks reticulation. The setation of the five-segmented palp (Fig. 3F) is $0-2-1-3-9$ (trochanter to tarsus), plus finely tapered tarsal solenidion $\omega$; four distal tarsal setae are eupathidial: $a c m, u l^{\prime \prime}, u l^{\prime}$ and $s u$, with the latter two being fused very close to 
their base. Chelicerae could not be studied in detail, but are visible through the prodorsum of the male paratype. The general shape is similar to that of $C$. johnstoni: chelate-dentate, strong, and slightly inserted into the body wall (i.e., the cheliceral sheath attaches at about $1 / 5$ of cheliceral length). Trägårdh's organ reaches beyond the condyle of the movable digit; seta cha $(\sim 50 \mu \mathrm{m})$ is slightly rough, thin, tapered, and chb $(\sim 45 \mu \mathrm{m})$ is smooth, thicker and blunt.

Legs. All legs are shorter than the body, but their proportions are dimorphic. In males (Figs. $1 \mathrm{~A}, 5)$ leg I is longest $(\sim 800-850 \mu \mathrm{m})$ and leg IV shortest $(\sim 600-700 \mu \mathrm{m})$, while in females (Fig. 2A) leg IV is longest $(\sim 800 \mu \mathrm{m})$ and leg II shortest $(\sim 600 \mu \mathrm{m})$. Overall thickness decreases posteriorly: in the holotype male, leg IV is notably thinner than I; tarsus I is about 1.5 times as thick as tarsus II, and twice as thick as tarsus IV. The three ambulacral claws are similar in form, with the central (empodial) claw slightly smaller than lateral claws; they are not distinctly barbed, but can be inconspicuously roughened on the dorsal curvature. Though not confirmed in all specimens, small porose areas (po, Fig. 2E) are present low on the anterior (') face of femora, genua and tibiae, associated with, and eccentric to, the respective ventral seta. The small genual pore $(g \cdot p)$, high on the posterior face of the genu, is located at midlength on genu I, but is basal on genu II, near the articulation, and at about $1 / 5$ the length of genu III (Fig. 5A, C, D).

Modifications of male leg IV are limited to the genu (Figs. 1E, F, 5G); the tibia is similar in length and lacks pustules or other surface irregularities. Hypertrophied genual seta $v^{\prime \prime}(45-50 \mu \mathrm{m})$ is thumb-shaped but broadened near the base, with an associated ridge on the outer face. The seta inserts at mid-height on the posterior face, close to the proximal end, and extends distally only to mid-length of the segment. The seta rises over a substantial, broad groove in the posterior face of the genu, which starts at the setal insertion and narrows distally.

Setal formulas for proximal segments are probably as follows: trochanters (1-1-2-2), femora $(6-6-5-3)$, genua $\left(5^{*}-5^{*}-4^{*}-4^{*}\right)$, tibiae $\left(6^{*}-6^{*}-\right.$ $\left.4^{*}-4^{*}\right)$; an asterix indicates that this count includes the minute seta $d$ vestige coupled to the respective solenidion (on genu and tibia I these are $\sigma_{1}$ and $\varphi_{1}$, respectively). Uncertainty comes from our inability to confirm the presence of $d$ in the available leg orientations due to the presence of a large coupled solenidion; it was seen directly only on one tibia II of the female, which had lost the solenidion (Fig. 2D), and on one genu I of the male paratype, but we assume it is present on all genua and tibiae, as in the other two Collohmannia species. Setal homologies on these segments are indicated on Fig. 5. Several structures were added to the figures of the holotype male legs, indicated by asterisks; their presence could not be confirmed on those legs but they are present in one or both paratypes. These include seta $d$ of genu I and tibia II, seta $l^{\prime \prime}$ of femora III and IV, the lyrifissure of tarsus IV, and the pore of genua I and II.

Tarsal setations are rich with proximal 'accessory' setae, as in other Collohmannia species, but these all have normal form in both sexes (no ribbonlike setae on tarsus I, as in the male of C. gigantea). The numerical formula of the holotype male is $\sim 40-30-25-22$, with that of tarsus I being uncertain. Variation can be expected on each tarsus (cf. C. johnstoni), but we could confirm only one instance: 26 setae on one tarsus III of the male paratype. A detailed analysis of tarsal setation is unfeasible, considering the available material, but it seems similar to that of $C$. johnstoni in having a pair of iteral setae on tarsi I-III (not IV) and proximal accessory setae in rows $l, c$ and $v$ on tarsus I (Fig. 4D), but only $l$ and $v$ on tarsi II-IV (e.g. Fig. 5E). Both male and female also have a few neotrichous setae high on anterior side of tarsus I (Figs. 4D, 5A). The famulus (e) is a slightly roughened spiniform peg $(\sim 10 \mu \mathrm{m})$ on tarsus I, located in the female between solenidia $\omega_{1}$ and $\omega_{3}$, and in the male closely abaxial to $\omega_{3}$. As in the other Collohmannia species, tarsus I is rich in eupathidial setae; these include seta $s$, pairs $(i t),(p)$ and $(p v)$, and approximately a dozen more proximal setae in $v$-and $c$-rows (Fig. 4D).

The solenidial counts are as follows: genu (2-1-1-1), tibiae (3-1-1-1), tarsi (6-2-0-0); their distribution and form are indicated in Figs. 4D and 5. Most solenidia are finely attenuate (piliform) to subflagellate; exceptions are $\omega_{1}$ and $\omega_{3}$ of tarsus I and $\omega_{1}$ and $\omega_{2}$ of tarsus II, which are less finely tapered and rounded at the tip (ceratiform). In both sexes, the shortest is $\sigma$ on genu IV. While six solenidia are present on tarsus I of both sexes, they are distributed differently. In the female (Fig. 4D), all are concentrated in the middle third of the segment, whereas in males (Fig. 5A) they are more dispersed; the position of $\omega_{2}$ is most different, being distal to seta $f t^{\prime}$ in the female, but proximal to it in males. 


\section{DISCUSSION}

Table 1 compares $C$. asiatica with the other two named extant Collohmannia species. Data for C. johnstoni derive from Norton and Sidorchuk (2014); those for C. gigantea derive from Sellnick (1932), Grandjean (1966), Weigmann (2006) and unpublished observations of specimens from Austria. Observed differences relate to most body regions, and all characters purported to distinguish C. johnstoni from C. gigantea (Norton and Sidorchuk 2014) could be studied in the type specimens of $C$. asiatica, except for cross-sectional proportions and structure of the spermatopositor apodeme. When the leg setation of C. asiatica and C. gigantea adults is better known, many other distinguishing characters might be identified.

Below, we consider the polarity of different character states in Collohmannia using outgroup comparison; size range $(1,2)$ is not considered since the sample of $C$. asiatica is so small. The sister-taxon of Collohmanniidae (the only family in Collohmannioidea) is not known, but a logical collective outgroup is an ensemble of non-ptyctime Mixonomata (Nehypochthonioidea, Perlohmannioidea, Epilohmannioidea) and Parhyposomata; see Norton and Behan-Pelletier (2009) for summaries and references. Not all similarities could be polarized with confidence. The most striking apomorphy of Collohmanniidae is the hypertrophication of male genu IV seta $v^{\prime \prime}(18)$, which is associated with the holding of nuptial food during courtship (Schuster 1962, Norton and Sidorchuk 2014), but no known outgroup has a modified $v^{\prime \prime}$ so comparisons are currently uninformative. A generally thumb-like shape is shared by $C$. asiatica and $C$. gigantea, while the presence of a broadened base and ridge is shared by C. asiatica and C.johnstoni. Similarly, all Collohmanniidae have some flagellate notogastral setae; $C$. asiatica and C. gigantea share a number lower than that of $C$. gigantea (6), but we are not confident about polarity or significance of these numbers. Outgroup comparison also leaves polarity of the several shapes of the bothridial seta $(3,4,5)$ unclear.

Three similarities are shared by C. asiatica and $C$. johnstoni, but not $C$. gigantea. Two relate to males and are almost certainly plesiomorphic, compared to a derived state in C. gigantea. First, like their females they have a modest number of proximal accessory setae in the lateral region, all of normal form; in C. gigantea that is true also of females but males are conspicuously neotrichous in this region, with the setae being long, ribbon-like
(15). Second, tibia IV lacks unusual surface features, whereas that of $C$. gigantea is strongly pustulate (17). A single possible apomorphy is shared by $C$. asiatica and C. johnstoni: the pore of genu I placed differently from that of II and III (11).

Similarity of $C$. asiatica to $C$. gigantea is greater (five characters). One of these similarities, the similar size of genu and tibia on tarsus IV of males (16), is probably symplesiomorphous, relative to a derived state in C. johnstoni. Four traits shared by $C$. asiatica and $C$. gigantea are considered synapomorphies. One relates to relative leg length (12): in the female of all three species leg IV is longest and II is shortest, and this is also true of the male of $C$. johnstoni and is a widespread pattern in oribatid mites; in C. asiatica and C. gigantea the male differs from the female, with leg I longest. A second relates to the size of tarsus I: in C. asiatica and C. gigantea tarsus I is considerably enlarged, relative to tarsus II (13), and is much thicker than tarsus IV. A third relates to the distal eupathidial setae $(\tau d)$ on the male spermatopositor (10); they are longer than other setae (e.g. $\tau p$ ) in $C$. asiatica and C. johnstoni; this seems apomorphic, since most oribatid mite spermatopositors, including that of $C$. johnstoni, lack long setae.

The fourth, and perhaps least equivocal synapomorphy is the presence of six solenidia on tarsus I (14) in C. asiatica and C. gigantea. Outside of Collohmannia, only Palaeosomata, the purported earliest derivative infraorder of oribatid mites, have as many as four solenidia on this segment, and the clear general pattern is for regressive losses in more derived higher groups (Grandjean 1964). This trend appears to be reversed in Collohmannia. Other members of Mixonomata have at most three tarsus I solenidia, and one could consider the count in $C$. johnstoni to represent a reversal, i.e., the atavistic reappearance of the fourth ancestral solenidion. But the six in $C$. asiatica and $C$. gigantea must represent the development of at least two new solenidia, perhaps through some duplication mechanism, and this is a clear synapomorphy.

These data are consistent with the palaearctic species $C$. asiatica and $C$. gigantea being more closely related that either is to $C$. johnstoni, which is known only from a small region of the Appalachian Mountains in the eastern USA. The two Baltic amber collohmanniids cannot yet be analysed in a cladistic context; $C$. schusteri is not yet known in sufficient detail, and Embolacarus pergratus is still known only from the brief original description. 


\section{ACKNOWLEDGEMENTS}

We are grateful to Dr. Andrey Zaitsev (Lomonosov Moscow State University, Moscow) for loan of the holotype male and to Dr. Andrei Tolstikov (Tyumen State University, Tyumen, Russia) for loan of paratype male and female. Dr. Manfred Walzl kindly provided specimens of $C$. gigantea from Krottendorf, Austria.

\section{REFERENCES}

Christov, V. V. 1970. [New species of the oribatid mites in the soils of Tajikistan]. In: E. M. BulanovaZachvatkina, M. S. Gilyarov, D. A. Krivolutsky, A. D. Petrova-Nikitina, I. S. Eitminavičiũte, and A. M. Aukshtikalnene (Eds). Oribatidy (Oribatei), ikh rol v pochvoobrazovatel'nykh processakh [Oribatei and their role in the process of soil formation]. Vilnius: Academy of Sciences of the Lithuanian SSR, pp. 155-160. [in Russian]

Grandjean F. 1964. La solénidiotaxie des Oribates. Acarologia, 6: 529-556.

Grandjean, F. 1966. Collohmannia gigantea Selln. (Oribate). Première partie. Acarologia, 8: 328357.

Norton, R. A. 2006. First record of Collohmannia (C. schusteri n. sp.) and Hermannia (H. sellnicki $\mathrm{n}$. sp.) from Baltic amber, with notes on Sellnick's genera of fossil oribatid mites (Acari: Oribatida). Acarologia, 46: 111-125.

Norton, R. A., and Behan-Pelletier, V. M. 2009. Chapter 15 , Oribatida. In: G. W. Krantz and D. E. Walter (Eds.). A Manual of Acarology, $3^{\text {rd }}$ Edition. Texas Tech University Press, Lubbock, pp. 421564.

Norton, R. A. and Sidorchuk, E. A. 2014. Collohmannia johnstoni n. sp. (Acari, Oribatida) from West Virginia (USA.), including description of ontogeny, setal variation, notes on biology and systematics of Collohmanniidae. Acarologia, 54: 271-334.
Norton, R. A. and Sidorchuk, E. A. 2015. Case 3674. Collohmannia Sellnick, 1922 (Arachnida, Acari, Oribatida): proposed conservation by giving it precedence over the senior subjective synonym Embolacarus Sellnick, 1919. Bulletin of Zoological Nomenclature, 72: 33-40.

Pfingstl, T., Krisper, G. and Schuster, R. 2005. Morphological analysis of the nymphal stages of $\mathrm{Col}$ lohmannia gigantea Sellnick (Acari: Oribatida, Collohmanniidae). International Journal of Acarology, 31: 367-374.

Schuster, R. 1962. Nachweis eines Paarungszeremoniells bei den Hornmilben (Oribatei, Acari). Naturwissenschaften, 49: 502.

Sellnick, M. 1919. Die Oribatiden der Bernsteinsammlung der Universität Königsberg i. Pr. In: Schriften der Physikalisch-ökonomischen Gesellschaft zu Königsberg $i$. Pr., Leipzig und Berlin, B. G. Teubner, pp. 21-42.

Sellnick, M. 1922. Milben der Sammlung des Deutschen Entomologischen Instituts. I. Oribatidae. Entomologische Mittelungen, 11: 18-20.

Sellnick, M. 1932. Oribatiden aus dem Karst. Zoologische Jahrbücher, Abteilung für Systematik, 63: 701-714.

Sidorchuk, E. A. and Vorontsov, D. D. 2014. Computer-aided drawing system-substitute for camera lucida. Acarologia, 54: 229-239.

Štorkán, J. 1925. Prispevky ku znamostem o ceskych Oribatidech (Acarina) [Additions to the knowledge of Czech oribatids (Acarina)]. Spisy vydávané Prírodovědeckou fakultou Karlovy University, 42: 1-40. [in Czech]

Travé, J. and Vachon, M. 1975. François Grandjean 1882-1975 (Notice biographique et bibliographique). Acarologia, 17: 1-19.

Weigmann, G. 2006. Hornmilben (Oribatida). Die Tierwelt Deutschlands, vol. 76. Goecke \& Evers, Keltern, 520 pp.

Table 1. Comparison of three extant species of Collohmannia based on morphological characters of adults ${ }^{1}$

\begin{tabular}{|l|l|l|l|}
\hline \multicolumn{1}{|c|}{ Character } & \multicolumn{1}{c|}{ C. asiatica } & \multicolumn{1}{c|}{ C. gigantea } & \multicolumn{1}{c|}{ C. johnstoni } \\
\hline 1. Total length of female & $1620 \mu \mathrm{m}$ & $1330-2025 \mu \mathrm{m}$ & $1542-1950 \mu \mathrm{m}$ \\
\hline 2. Total length of male & $1160-1247 \mu \mathrm{m}$ & $1282-1620 \mu \mathrm{m}$ & $1435-1689 \mu \mathrm{m}$ \\
\hline 3. Bothridial seta length & $\begin{array}{l}\text { less than mutual distance } \\
\text { of setal pair } \text { in }\end{array}$ & $\begin{array}{l}\text { less than mutual distance } \\
\text { setal pair } \text { in }\end{array}$ & $\begin{array}{l}\text { greater than mutual } \\
\text { distance of setal pair } \text { in }\end{array}$ \\
\hline 4. Bothridial seta shape & $\begin{array}{l}\text { isodiametric (female) to } \\
\text { weakly clavate (male) }\end{array}$ & isodiametric & $\begin{array}{l}\text { distally tapered, with } \\
\text { weak S-curve near } \\
\text { middle }\end{array}$ \\
\hline
\end{tabular}




\section{E. A. Sidorchuk and R. A. Norton}

\begin{tabular}{|c|c|c|c|}
\hline 5. Bothridial seta surface & $\begin{array}{l}\text { barbed along full length } \\
\text { but strongest distally }\end{array}$ & small terminal barbs & $\begin{array}{l}\text { minute, sparse barbs } \\
\text { along length }\end{array}$ \\
\hline 6. Flagellate notogastral setae ${ }^{2}$ & $\begin{array}{l}3\left(e_{1}, h_{2} \text { similar, } p_{1} \text { about }\right. \\
\left.\text { half } h_{2} \text { in male }\right)\end{array}$ & $3\left(e_{1}, h_{2}, p_{1}\right.$, all similar $)$ & $\begin{array}{l}5\left(e_{1}, e_{2}, h_{1}, h_{2}, p_{1}, \text { all }\right. \\
\text { similar })\end{array}$ \\
\hline 7. Form of seta $h_{1}$ & short, stiff, acute & attenuate, moderate length & flagellate \\
\hline 8. Size of seta $e_{2}$ & $\begin{array}{l}\text { small, inconspicuous, } \\
\text { similar to } f_{2}\end{array}$ & $\begin{array}{l}\text { attenuate, more than twice } \\
\text { length of } f_{2}\end{array}$ & $\begin{array}{l}\text { flagellate, many times } \\
\text { longer than } f_{2}\end{array}$ \\
\hline 9. Size of setae $a d_{1}, a d_{2}$ & $\begin{array}{l}\text { twice thickness of anal } \\
\text { setae (and } a d_{3} \text { ) }\end{array}$ & $\begin{array}{l}\text { slightly thicker than anal } \\
\text { setae }\end{array}$ & $\begin{array}{l}\text { slightly thicker than anal } \\
\text { setae }\end{array}$ \\
\hline $\begin{array}{l}\text { 10. Relative size of eupathidia } \\
\tau d \text { and } \tau p \text { of spermatopositor }\end{array}$ & $\begin{array}{l}\tau d \text { conspicuously longer } \\
\text { than } \tau p\end{array}$ & $\begin{array}{l}\tau d \text { conspicuously longer } \\
\text { than } \tau p\end{array}$ & $\begin{array}{l}\tau d \text { and } \tau p \text { short, similar } \\
\text { in length }\end{array}$ \\
\hline 11. Position of genu I pore & near middle of segment & $\begin{array}{l}\text { proximal, near articulation } \\
\text { (as on II, III) }\end{array}$ & near middle of segment \\
\hline $\begin{array}{l}\text { 12. Relative leg length, } \\
\text { decreasing order }(/=\text { about } \\
\text { equal) }\end{array}$ & $\begin{array}{l}\text { I-III-II-IV (male); } \\
\text { IV-I/III-II (female) }\end{array}$ & $\begin{array}{l}\text { I-IV-II/III (male); } \\
\text { IV-III-I-II (female) }\end{array}$ & $\begin{array}{l}\text { IV-III-I-II (male); } \\
\text { IV-III-I-II (female) }\end{array}$ \\
\hline 13. Tarsus I shape & $\begin{array}{l}1.5 \text { times thickness of } \\
\text { tarsus II }\end{array}$ & $\begin{array}{l}\text { almost twice thickness of } \\
\text { tarsus II }\end{array}$ & $\begin{array}{l}\text { thickness about same as } \\
\text { tarsus II }\end{array}$ \\
\hline 14. Tarsus I solenidia & 6 & 6 & 4 \\
\hline 15. Male tarsus I setation & similar to female & similar to female & $\begin{array}{l}\text { Unlike female; with } \\
\text { neotrichy of long } \\
\text { ribbon-shaped setae in } \\
\text { lateral region }\end{array}$ \\
\hline $\begin{array}{l}\text { 16. Relative size of genu/tibia } \\
\text { on male leg IV }\end{array}$ & $\sim 1: 1$ & $\sim 1: 1$ & $\sim 1.8 / 1$ \\
\hline 17. Form of male tibia IV & unmodified & $\begin{array}{l}\text { with dense dorsolateral } \\
\text { pustules }\end{array}$ & unmodified \\
\hline $\begin{array}{l}\text { 18. Hypertrophied seta } v " \\
\text { of male genu IV }\end{array}$ & $\begin{array}{l}\text { thumb-like, broadened } \\
\text { near base with associated } \\
\text { ridge on outer face; with } \\
\text { proximal insertion (tip } \\
\text { reaching only mid-length } \\
\text { of segment) }\end{array}$ & $\begin{array}{l}\text { thumb-like, not broadened } \\
\text { at base; inserted near } \\
\text { mid-length (tip reaching } \\
\text { distal articulation) }\end{array}$ & $\begin{array}{l}\text { asymmetrical diamond, } \\
\text { broadened near base } \\
\text { with associated ridge; } \\
\text { inserted near mid-length } \\
\text { (tip exceeding distal } \\
\text { articulation) }\end{array}$ \\
\hline
\end{tabular}

${ }^{1}$ Data sources are indicated in the text.

${ }^{2}$ Homologies of notogastral setae follow Norton \& Sidorchuk (2014); they differ from the interpretation of Grandjean (1966) in the reversed identity of setae $e_{1}$ and $d_{1}$. Notogastral setae considered flagellate are those at least as long as prodorsal seta $i_{\mathrm{n}}$. 